\title{
Indigenous Peoples' Rights and Cultural Heritage: Threats and Challenges for a New Model of Heritage Policy
}

\section{Derechos de los pueblos indígenas y patrimonio cultural: amenazas y desafíos para un nuevo modelo de política de patrimonio}

\section{Marta Kania*}

ABSTRACT: The purpose of this article is to analyze the condition of indigenous peoples' rights in the context of the protection, safeguard and management of their cultural heritage, especially those elements which have been recognized as of "outstanding universal values" and inscribed on the UNESCO World Heritage List. As the territory of reference, I chose the Latin American area. I point out the negative aspects of the political appropriation of the cultural heritage and the implications of its designation as a World Heritage for indigenous peoples. Referring in particular to the international documents and analyzing the content of the recommendations and reports adopted in recent years by the UN-system, I also try to identify the positive social initiatives and political practices.

Key words: Heritage; Culture Politics; Indigenous Peoples Rights; Decolonization; Latin America.

RESUMEN: El propósito de este artículo es analizar la situación de los derechos de los pueblos indígenas en el contexto de la protección, salvaguardia y gestión de su patrimonio cultural, especialmente aquellos elementos que han sido inscritos en el Lista del Patrimonio Mundial de la unESco. Señalo los aspectos negativos de la apropiación políitica de los elementos del patrimonio cultural y las implicaciones de su designación como Patrimonio Mundial para los pueblos indígenas. Como territorio de referencia elegí el área de América Latina, Al referir los documentos internacionales y analizando el contenido de las recomendaciones e informes adoptados en los últimos años por el sistema de las Naciones Unidas, trato asimismo de identificar los procesos positivos de las iniciativas sociales y las prácticas políticas.

Palabras Clave: Patrimonio; Política cultural; Derechos de los pueblos indígenas; Descolonización; América Latina.

Recibido: 12 de marzo de 2018

Aceptado: 3 de septiembre de 2018

* Universidad Jaguellónica, Cracovia (martha.kania@uj.edu.pl). 


\section{INTRODUCTION}

he rights of indigenous peoples to prior consultation, territory,
autonomy and cultural heritage, among others, although gua-
ranteed by different international regulations and conventions
ratified by national governments, face serious challenges when it comes to their effective implementation. ${ }^{1}$ However, both the struggle of the indigenous peoples, who decide to take advantage of the existing legal mechanisms to exert international pressure and the growing awareness of socio-political changes have brought some progress in the matter, which should be identified. Therefore, the purpose of this article is to analyze the situation of indigenous peoples' rights in the context of the protection, safeguarding, and management of their cultural heritage, especially those elements which have been recognized as of "outstanding universal values" (Ouv) and have been introduced to the UNESCO World Heritage List. I point out the negative aspects of the political appropriation of the cultural heritage elements (most sites and monuments) and the implications of their World Heritage status for indigenous peoples' rights to access and use of territories or sacred objects. Recalling the international documents (like UNESCO's Conventions and un Declarations) and analyzing the content of the recommendations and reports adopted in recent years by the un-system, I also try to identify some positive aspects of the issue, being aware of the ongoing process of constructive social initiatives and of the introduction of good political practices dedicated to the protection, preservation, and management of the indigenous peoples' cultural heritage. As a territory of reference, I chose Latin America, an area of significant and dynamic changes in contemporary heritage policy and territory, where heritage issues become an instrument in the struggle for the implementation of indigenous peoples' rights, and an essential notion

1 Article based on investigations undertaken as part of a research grant of National Center of Science in Poland (NCN 2017/01/X/HSP/01 628) and a research proyect of Support Program for Research Proyects and Technological Innovation of UNAM (PAPIT UNAM IN300617, México 2017-2019). 
in decolonization discourse. The processes of $21^{\text {st }}$-century socio-political changes, in particular, those related to the modern conception of cultural rights and cultural plurality, have introduced both the positive phenomena in the way of social use and protection of cultural heritage, as well as many doubts about its adequate and respected safeguard. In the political discourse on this issue, much attention is given to the processes of globalization, social transformation under the pressure of adaptation to modern technology or the dynamic development of mass-tourism. The last issue provokes questions of proper conservation, promotion, and commercialization (vide trivialization) of the elements of cultural heritage. No less important is the question of guaranteeing of the free access to and use of the elements of cultural heritage by all members of national societies.

In the case of the term "indigenous peoples", there is no one universal and unambiguous definition of the concept since no single accepted description captures the diversity of indigenous cultures and current circumstances in which people belonging to this group live all over the World. As this paper is about the relations between the State, international cultural agendas and political practices related to indigenous peoples' heritage and not strictly about the status of indigenous peoples nor the criteria for their identification, I accept the definition proposed and most commonly used in the international social and political discourse, being aware of the complexity of the problem and the imperfection of generalization. Special-Rapporteur José Martínez Cobo in his Study on the Problem of Discrimination against Indigenous Populations, reported to the un Sub-Commission on the Prevention of Discrimination of Minorities (1986) states, that indigenous peoples are:

those which, having a historical continuity with pre-invasion and pre-colonial societies that developed on their territories, consider themselves distinct from other sectors of the societies now prevailing in those territories, or parts of them. They form at present non-dominant sectors of society and are determined to preserve, develop and transmit to future generations their ancestral territories, and their ethnic identity, as the basis of their continued existence as peoples, in accordance with their own cul- 
tural patterns, social institutions and legal systems (Martínez Cobo 1986: 379-382).

Martinez Cobo's criteria are reflected in the definition approved by the International Labour Organization (ILO) in the Convention Concerning Indigenous and Tribal Peoples in Independent Countries no. 169 (in force since 1991). ${ }^{2}$ The ILO Convention underlines the self-identification as indigenous as a crucial criterion for determining the groups to which the provisions of Convention apply (ILO Convention 169). This feature was also adopted by the UN-system - according to the UN the most fruitful approach is to identify, rather than to define indigenous peoples, based on the fundamental criterion of self-identification. The un Declaration on the Rights of Indigenous Peoples, adopted by the General Assembly in 2007 (here and after UNDRIP 2007) in Article 3 states that: "Indigenous Peoples have the right to self-determination. Under that right, they freely determine their political status and freely pursue their economic, social and cultural development" (UNDRIP 2007). ${ }^{3}$ This standard also appeared in American Declaration on the Rights of Indigenous Peoples, adopted $15^{\text {th }}$ of July, 2016 during the $46^{\text {th }}$ regular session of General Assembly of the Organization of American States in Santo Domingo. It offers specific recommendations for the protection of the rights of American indigenous peoples to self-determination and self-government, education, health,

2 The Article 1.b states, that the Convention concerns "peoples in independent countries who are regarded as indigenous on account of their descent from the populations which inhabited the country, or a geographical region to which the country belongs, at the time of conquest or colonisation or the establishment of present state boundaries and who, irrespective of their legal status, retain some or all of their own social, economic, cultural and political institutions" (ILO Convention 169). Convention ILO 169 was ratified and adopted by 22 countries, including almost all countries in Latin America: México (1990), Plurinational State of Bolivia (1991), Colombia (1991), Paraguay (1993), Costa Rica (1993), Peru (1994), Honduras (1995), Guatemala (1996), Ecuador (1998), Argentina (2000), Venezuela (2002), Brazil (2002), Chile (2008) and Nicaragua in 2010 (Base de Datos...; www.ilo.org).

3 UNDRIP 2007 was adopted with a majority of 144 states in favor, including all countries in Latin America, except Colombia, which initially abstained it in 2007, but later support and acceded to it in 2009. 
culture, lands, territory, and natural resources, although with principles of territorial integrity and sovereignty of the State.

It is worth noticing that the definitions mentioned above have emerged due to the need to find a consensus in the long-term tense relations between indigenous peoples and the dominant group of national societies. In Latin America, throughout almost the whole of the $20^{\text {th }}$ century persisted the regimes of internal colonialism, which where carried out through assimilationist policies aiming to eliminate ethnic and cultural particularities in the name of progress and development. Populist tendencies in most countries favored economic protectionism and cultural domination over an indigenous sector of the population. It was assumed that in order to protect indigenous peoples it was necessary to integrate them into the national culture and state-parties took the responsibility of approriating population the values and cultural heritage of the indigenous for reasons related to modernity and development within the structures of homogeneous nation-states. Only at the turn of the $20^{\text {th }}$ century, after decades of resistance, struggle and protests, thanks to growing institutional representation led by their leaders, indigenous communities have gained international attention and provoked the revision of existing status as marginalized and subordinated part of national societies (Stavenhagen 2002; Peña de la 2005; Stavenhagen 2009). What is crucial for this paper is the recognition, that indigenous peoples are the holders of unique culture, expressed by languages, knowledge systems or beliefs. They also have a particular relation to their lands and territories, possessing vital knowledge of practices indispensable for the sustainable management of natural resources. Indigenous peoples hold their distinct concepts of development, based on their traditional values, visions, needs, and priorities. In relation with the heritage policy issue, they are recognized as custodians and stakeholders, not only as heirs and descendants of past generations.

Regarding the term "heritage", it should be emphasized that nowadays it is interpreted ambiguously, as a subject under constant change, which continually expands and enriches its semantic range. The World 
Heritage Convention of $1972^{4}$ however, and subsequent Operational Guidelines for the World Heritage Committee have provided its static definition, divided into categories: cultural heritage (monuments, groups of monuments, and sites), natural heritage (exp. geological, physical or biological formations, natural areas), mixed cultural and natural heritage and cultural landscapes (unEsCo Convention 1972; Operational Guidelines 2016, Chapter II.A, paragraphs 45-47). In 2003, with the adoption of unESCO Convention for the Safeguarding of the Intangible Cultural Heritage, the separate category of intangible cultural heritage was defined as the practices, representations, expressions, as well as the knowledge and skills (including instruments, objects, artefacts, cultural spaces), that communities, groups and, in some cases, individuals recognize as part of their cultural heritage. This category of heritage is sometimes called "living cultural heritage" and is manifested inter alia in oral traditions, performance arts, rituals, knowledge, and practices related to nature, knowledge, and techniques linked to the traditional craftsmanship, inherited and transmitted from generation to generation. ${ }^{5}$

The World Heritage Convention was adopted in 1972, before most of the significant international steps that have been taken over the past decades to recognize and protect the rights of indigenous peoples. The

4 Officially: Convention concerning the Protection of the World Cultural and Natural Heritage", adopted by the General Conference of unESCO in Paris in November 1972. The Convention was ratified by all Latin American countries successively in the 1970s (Argentina, Bolivia, Brazil, Costa Rica, Ecuador, Guatemala, Honduras, Nicaragua, Panama), 1980. (Chile, Colombia, Cuba, Mexico, Paraguay, Peru and Uruguay) and 1990. (El Salvador in 1991 and Venezuela in 1990). The signing of the Convention is a clear acceptance of UNESCO's understanding of the concept of "heritage" and the acceptance of obligations arising from the status as a signatory country in the scope of protection and preservation of cultural and natural heritage. State Parties that have ratified the Convention may submit proposals for nominations for the World Heritage List of those elements of cultural or natural heritage that are located in their territories.

5 The Convention entered into force on April 20, 2006, but was ratified already in 2005 by México and Peru, followed by most Latin American countries in 2006 (Argentina, Bolivia, Brazil, Guatemala, Honduras, Nicaragua, Paraguay), 2007 (Belize, Costa Rica, Cuba, Uruguay, Venezuela) and during subsequent years (Ecuador 2008, Chile 2008, Colombia 2008, Haiti 2009, El Salvador 2012). 
Convention, therefore, does not refer to or reflects these essential steps and is, in fact, in some ways at odds with them. The primary goal of the World Heritage Convention is the identification and collective protection of cultural and natural heritage sites of "outstanding universal value", and for this purpose, UNESCO Committee created the list of sites known as a World Heritage List (with first nominations in 1978). The List, on the one hand, remains the key element of UNESCO's work, symbol of prestige and of what is best recognizable in heritage matter by the global public, but on the other hand is also in the core of criticism and ongoing debate about the principles of the protection and respect of indigenous people's cultural rights, as many objects referred to as of "outstanding universal value" are at the same time elements of the local cultural heritage and part of indigenous cultural patrimony, source of indigenous peoples' identity and reference point for political requests. In Latin America one can point such well-known pre-Columbian sites from unESCO List like Teotihuacán, El Tajín, Monte Albán or Chichen Itzá in México, Tikal in Guatemala, Copán in Honduras, Machu Picchu, Chan Chan and Q'eswachaka Bridge in Peru or Tiwanaku in the Plurinational State of Bolivia. Moreover, Machu Picchu and Chichen Itzá are those World Heritage sites that are included on the List of modern Seven Wonders of the World, announced on July 7 , 2007 , in Lisbon.

For this paper, I accept the general concept of heritage as proposed in World Heritage Convention, aware however that the division between the tangible and intangible cultural heritage is more a practical than a real one, as they are complementary. Regarding the term in the context of indigenous peoples' heritage arbitrary division between cultural and natural heritage has also been criticized. Already in 1990, un Commission on Human Rights promoted studies leading to the revision of existing legacy definitions of heritage in the un-system. It was pointed out, that a strict separation between cultural and natural heritage (as enshrined in 1972 Convention) is inappropriate and can force its mercantilist exploitation, penalizing indigenous conceptions of holistic perception of culture as a way of life that includes not only products of human thought and crafts- 
manship, but also natural features, landscape and all relations between community and other human beings or non-human, spiritual creatures (Gilbert 2014, 56; Smith 2006). Erica-Iréne Daes, Special Rapporteur of the United Nations Working Group on Indigenous Populations insisted on the adoption of a broad, holistic definition of indigenous peoples' heritage: "The 'heritage' includes all expressions of the relationship between the people, their land and other living beings and spirits that share that land, and is the basis for maintaining social, economic and diplomatic relations with other peoples, with whom it is shared. All aspects of heritage are related to each other and cannot be separated from the traditional territory of certain people" (1997, para. 164). In the same document, the heritage was defined as "everything that is part of the characteristic identity of a people, which can be shared, if desired, with other peoples" (Daes 1997, para. 24). In these terms, heritage is a matter of "individual and collective responsibility" (Daes 1997, para. 26), and therefore it must be considered as an inalienable and indivisible collective right.

Studies on the social and political use of heritage are diverse, and it would be a truism to say that heritage has different meanings, beyond aesthetic or scientific aspects. From the 1990-2000 decade, the social sciences interest heritage underlines its role both in social and economic development of given communities and construction of identity in local, national and international dimension and also as a source of the conflicts and tensions in international and interethnic relations. Studies on heritage are at the same time inquieres on the methods and ways in which communities build their past and an inspiration for actions taken in the future. The fact, that heritage it is not something given, or a condition inherent in an object, but that it constitutes a social construction became a crucial point for political studies related to heritage issues. From this perspective, heritage would be closer to a process than to something predefined and static, even more like "heritage manufacture", named "patrimonialization" (Davallon 2002). Gregory Ashworth (2015: 91-104) as well as Barbara Kirshenblatt-Gimblett, who emphasize that the patrimonialization hast to do with the negotiation of memory, identity and sense of place (Kirshenblatt-Gim- 
blett 1998, 7; 149). It is an active process of choosing, remembering, forgetting and commemorating, as well as a type of consensus reached by a particular group of actors to select, activate and legitimize certain cultural goods and manifestations above others, based on different points of view. Different social uses characterize the different ways in which society relates to the past and interprets its symbols, can offer us clues to understand various dynamics of the patrimonialization process.

\section{HERITAGE IN CONFLICT: FROM LOCAL TO GLOBAL}

In the last few decades, heritage has become a matter of political and economic negotiations between "heritage agents" and representatives of indigenous peoples under the line of basic queries: who has the right to dispose and manage and who should dispose and control heritage and its symbols? Who is the proper custodian of the material or intangible cultural heritage at the time when it becomes a symbol of the national heritage or a symbol of "outstanding universal value", inscribed on the World Heritage List? Who should possess control over profits generated by mass-tourism and popularity of World Heritage sites located on the territories of indigenous peoples? How can indigenous communities protect their rights to lands, territories, and resources (understood and recognized as fundamental for their identity, development, and persistence) from the political and economic appropriation by "heritage agents" and aggressive global tourist market?

It should be noted that the process of evaluation of the heritage objects or sites and their inclusion to the category of World Heritage is being applied only by countries that have signed the World Heritage Convention and that only the governments of the member-states can submit nomina-

6 Under the term of "heritage agents" I understand States and their institutional structures, professionals, international agendas dedicated to conservation and protection of heritage, mainly representatives of UNESCO and ICOMOS and other non-indigenous specialists. 
tion proposals for properties on their territory. Consequently, adequate protection, conservation, and management of cultural objects and sites that are important for indigenous peoples depend on the government's cultural policy and reflect the ongoing character of the relationship between the indigenous community and state's heritage agendas. As has been mentioned, in the World Heritage Convention there are no necessary provisions on the rights of indigenous peoples. In many cases, indigenous groups have not been even consulted when their territories were designated as World Heritage sites, although designation for the famous List could have far-reaching consequences for their lives. This is probably due to the early adoption of Convention, in times when little attention was given to self-determination and the cultural rights of indigenous peoples and even less to the respect for their rights to participate in the management of places declared as World Heritage. The politicization of the nomination and the subsequent management processes can be regarded also as a result of an economic pressure related to the need for national/ regional development and the international competition for investment. Although the purpose of the UNESCO World Heritage Convention is generally to protect the global merit good of cultural and natural heritage of outstanding value for Humanity, World Heritage List is perceived also as a brand in global rivalry for international tourism and as an instrument of promotion of particular sites as tourist destinations (Baud, Ypeij 2009; Askew 2010; Bertacchini et al. 2016; Maurel 2017).

Considering these factors, in many Latin American countries, the inclusion on the List represents the most favorable outcome for a country, as it provides several types of benefits, ranging from international prestige to additional financial resources from tourism or international aid for conservation. The majority of sites and objects inscribed on the World Heri-

Authors of the critical article "The Politicization of unEsCo World Heritage decision making" (2016) even hypothesize that, although in the $20^{\text {th }}$ century, the intentions of nominations and entries in the World Heritage List were mainly to protect global cultural and natural heritage from decay, erosion, and destruction, today designations are referred to their economic potential and future benefits for countries able to market World Heritage sites for tourism (Bertacchini et al. 2016). 
tage List are monuments and places related to pre-Hispanic (indigenous) patrimony. We are witness of a certain paradox: heritage sites must meet certain standards of universalism designated by the "UNESCO logo" and the symbol of world heritage, but on the other hand, they are supposed to present uniqueness and particularity of culture, which should be an attraction for crowds of tourists. Indigenous peoples' heritage is presented as a unique and the most attractive symbol of the past that has been preserved over the centuries to be studied by scientists or to be admired by tourists. The dynamic development of mass-tourism, ${ }^{8}$ and in particular cultural tourism (also named heritage tourism, ecotourism or ethnotour$i s m$ ) that observed during the last few decades in the region, entails therefore important consequences for indigenous peoples' status and rights. The monuments and places of cultural heritage inscribed on the World Heritage List may bring tourism revenue and thus economic profits, so nomination and inscription on the List are usually highly desired. As a result, sites and monuments inscribed on the List become not only symbols of national identity but also globally recognized icons, "visiting cards" of the countries where they are located, and they are included in the global network of tourism infrastructure (vide Cusco and Machu Picchu in Peru, Teotihuacán and Chichen Itzá in México, Tikal in Guatemala, Copán in Honduras or Tiwanaku in Plurinational State of Bolivia). Unfortunately, the inscription on the List can lead to serious violations of the rights of the indigenous peoples that inhabit in or around the heritage sites. In some World Heritage areas indigenous peoples are essentially treated as threats to their territories, and to the infrastructure and tight restrictions and prohibitions are imposed upon on their traditional land-use practices

8 Latin America during the last few decades becomes the territory of one of the most dynamic developments in global tourism (mass-tourism). According to un World Organization of Tourism (UNWTO 2016) only in 2015, there were 1.186 million international tourists on the global scale, with over 97 million in Latin America and Caribe. In each region, there was a considerable increase in international arrivals concerning the last years (2010-2014): in America Central 7\%, Caribe 7\%, and South America 6\%. The incomes generated by tourism in 2015 constitute over 82 million USD (Panorama OMT del Turismo...). 
such as hunting, gathering, farming or animal husbandry. The system of patrimonial management enforced by western norms of conservation and under the political-economic strategies of "heritage agents" is leading to the appropriation of the sites and heritage objects under the centralist control and patronage of the State, and therefore to the process of internal colonialism. The heritage sites become and are treated as "open-space museums", untouchable by traditional residents named even "invaders" to their own territories. Excessive cleaning activities or improper reconstructions can cause the loss of coherent, integral character of the heritage site and distort its original meaning. Becoming a part of National Heritage or an element of World Heritage, many places lose their original important social function. Prohibition of agricultural labor, ritual activities and in general any presence of inhabitants on the arbitrarily delimited and confined zones of heritage sites are turning formerly important social spaces into "abstract" and "sterile" ones. As Pablo García noted about Inca constructions in Chinchero, Peru: "This abstract space is physically clean and visually unobtrusive, but it is also deprived of mystery, easily packaged and consumable, and devoid of cultural and religious meaning" (García 2017: 338).

The appropriation is already visible in the very language that is used for the heritage elements: indigenous gentiles, achachilas, abuelitos (ancestors); local buacas (sacred spaces and places), places of contact and passage, shrines or temples become now "ruins", "archaeological sites", "tourist destination", "tourist attraction", "historic monuments" and last but not least "patrimony", "National Heritage" or "World Heritage". The presence of inhabitants and their daily practices are denied, mainly because they do not fit into the vision of a "National Heritage" or "cultural heritage of the Humanity" In some cases, they are not accepted because they are "not indigenous enough" or "authentic" (by using modern clothes, cell-phones or cars). The expulsion of indigenous peoples or the access restriction to the cultural heritage sites eliminates what, in my opinion, has the most important regarding heritage: its continuity and 
persistence, as well as the transmission of its elements from generation to generation (Disko 2010; Cleere 2011, García 2017; Kania 2017).

The matter of recognition and respect of indigenous peoples' rights related to cultural heritage is inherent to the issue of the free access and the use of the sites and objects that form their cultural landscape: sacred places, sanctuaries and cult objects, traditional routes, structures related to creativity and artistic production or small industry. This access could be hampered for several reasons - inclusion in the inventory of national heritage and most of all in the World Heritage List requires that governments (via their heritage agendas) apply appropriate provisions for the conservation and protection of the cultural heritage structures, as well as for the control over their maintenance, management, and promotion. Therefore, a special protection zone is delimited (named "Culture Park" or "Archaeological Park"), which is monitored and controlled by state institutions and international organizations, and to which most frequently the entrance is charged.

Free access and right to present itself as the heirs of "protected heritage" are also complicated due to limits of daily visits or the high prices of the tickets. Thus, with the consent of a national and international group of experts, a process of expulsion is carried out, sometimes precisely of the direct descendants of the constructors of the historical heritage that is protected. Conflicts and tensions between "heritage agents" and groups that named themselves stakeholders of heritage elements and demand access and participation in the management of heritage sites can be observed in Yucatan, México (Chichen Itzá, Palenque), Guatemala (Tikál), Bolivia (Tiawanaku) or Peru (Machu Picchu). Economic appropriation of those sites and monuments, presented as attractive tourism destinations would also be incomprehensible and do not correspond to the value system of indigenous peoples, as they do not recognize the economic value of places and objects (in particular those related to the sacrum sphere). As Erica-Irene Daes indicates: "Indigenous peoples do not see their heritage as a property at all - that is, goods that have an owner and that are used to obtain economic benefits [...]. For indigenous peoples, heritage 
is more a set of relationships, than a set of economic rights" (Daes 1997; see also: Endere 2014; Smith 2006: 277-282; Disko, Tugendhat, García-Alix 2014). Introduction of technical facilities and modern infrastructure in the heritage sites, with the purpose to improve visitors' statistics and generate significant economic profits, poses yet another controversy related to the mass-tourism. One of the most pronounced, striking examples in Latin America was the international debate in the 1990s about the installation of the cable car to the Inca city Machu Picchu (on UnEsCo's List of World Heritage Sites since 1983). In the capital of Peru, Lima, the construction was presented as a symbol of the extensive investment plans and economic development of the entire Machu Picchu District. However, among the inhabitants of the Department of Cusco and the neighboring population of the Inca city (perceiving themselves as direct descendants and heirs of Inca heritage), the decisions made by the authoritarian government of President Alberto Fujimori, were called sacrilege, desecration of a sacred place and the "false modernization" destroying authenticity and integrity values of the site (Martorell 2000: 120-124; see more: Kania 2013). Unwavering resistance of local and international communities managed to defend the Machu Picchu Sanctuary from centralist decisions, but he idea of the cable car has returned in recent years. The current decisions related to the regulation of mass-tourism movement in both, the Sanctuary, and in the famous Inca Trail indicates, that Machu Picchu plays a too essential role in the economic plans of Peru's government to be left only in the hands of defenders of cultural heritage and human rights. ${ }^{9}$

Another questionable aspect is that of the excessive cleaning and sanitizing of historical settlements (that I call "heritage lifting"), thereby creating some kind of "heritage decorations" in the name of an image of

9 The problem of over-exploitation of the site (the proposition of two rounds of visitors per day, which double already high number of tourists), wrong decisions related to the development of tourist and transport infrastructure and the gradual loss of control over mass-tourist traffic in the Urubamba Valley and Historic Sanctuary of Machu Picchu led to the warnings that the site should be put on the site on the list of World Heritage in danger. This issue was the subject of discussion during $41^{\text {st }}$ session of World Heritage Committee held in Cracow (2-12 July 2017). 
places and structures, re-created (or even re-invented) in accordance to the commercial and tourist needs, international promotion outlines or in particular, imposed vision about local culture. False reconstructions that we can call "conservation for the sake of the public" are performed, some elements are eliminated (for example any traces of recent activity), some replaced by the features that are in line with the officially accepted discourse on national heritage. In this context the so-called "archaeology for the public" is also an important issue: an effort of the culture agents to create a particular, "authentic" vision of a National Past and cultural achievements of the Fathers of the Nation, according to the one, classic image of historical heritage, and disregarding of those elements of heritage that do not correspond to the political goals and vision. As an example, we can mention here an Aztec image of the Mexican or an Inca image of the Peruvian national archaeological projects of the $20^{\text {th }}$ century, with far less interest for non-Aztec or non-Inca sites and objects.

An analysis of the cultural heritage management system inclines, therefore, to look at this issue both in the context of the conservation and promotion of the objects and sites and in the context of the rights of indigenous peoples to the protected territories and monuments. Regulations established to ensure adequate control of the space by the State and its representatives can alter the relationship between the residents and the places. Dislodging the people and the animals from the heritage sites constitute the first step in the sterilization and standardization of the space. As García noted: "By insulating and restoring monuments, by polishing them and concealing the blemish of time from them, they have been turned into a-temporal monument" (García 2017, see also: Smith 2006; Askew 2010; Cleere 2011). On the other side, indigenous peoples' limited participation in the nomination and inscription of World Heritage sites, their marginalization in the on-site decision-making management of World Heritage areas, violations of their right to share equitably in tourism benefits, and forced displacement are interpreted as endocolonialismo (internal colonialism). The above-mentioned issues began to be reported 
by indigenous communities as both violations of human rights and indigenous peoples' culture rights guaranteed by the un-system. ${ }^{10}$

\section{RECOGNITION OF THE NEW ACTORS}

in Heritage Policy on InTERnational Forum

The shift from military dictatorships to democracy which took place in many of Latin American countries in the second half of $20^{\text {th }}$ century has led to the revision of the existing social relations and elaboration of new paradigms in social and cultural policy. The discourse between the State and indigenous peoples become the critical issue of the reforms introduced at the end of the $20^{\text {th }}$ century. The leaders (recognized as cultural brokers), using the notions of neo-Indigenism/Indianism, international declarations on human rights and discourse of decolonization have deconstructed existing political theories and social standards, demanding new spaces for participation as citizens in their national societies. The primary goal of the indigenous protests and subsequent debates and mediations with the state authorities were such postulates as a guarantee of human rights, citizenship, and recognition of the ownership of territories occupied over the centuries, as well as demands for the introduction of a cultural autonomy based on the principles of multiculturalism. Such ideas were presented in the program of various organizations of the Mapuches

${ }_{10}$ Restrictions on the free access to the sites that are important for indigenous peoples as the symbols of their cultural identity and a sense of their persistence can be observed both through the forced or indirect displacement of indigenous peoples, and through the other factors affecting heritage sites, related to commercial and industrial areas development, construction and use of transport infrastructure, excessive mining, social uses that lead to the deterioration of heritage sites and environmental degradation, as well as deliberate destruction of heritage object and monuments due to vandalism or looting. All those problems are significant issues of public politics related to the protection and safeguarding of cultural heritage developed in almost every Latin American country, notably in reference to the objects and sites related to the classic civilizations of Aztecs, Mayas and Incas in México, Guatemala, Perú, and Bolivia. 
in Chile, Aymaras in Altiplano or the Mayas in Chiapas and north Yucatan. On the basis of articulated needs, the idea of etnodesarollo (ethnic-development) was created, emphasizing the necessity of modernization and progress, but with the maintenance of distinctive cultural identity, based on the values of one's own culture and tradition inherited from the ancestors (see more: Lee Van Cott 2000; Posern-Zieliński 2009; Stavenhagen 2009; Stavenhagen 2012).

Latin American processes constituted the echo of the worldwide debate on the rights of indigenous peoples and response to demands of a new social and cultural policy, based on the concepts of multiculturalism, cultural rights, participation management, autonomy and, in consequence, the new model of pluralist states. As a result of the efforts in the field of cultural policies and promotion of the cultural rights in ILO Convention no 169 a significant number of laws on protection, safeguarding and promotion of cultural diversity was introduced and adopted. Both the Preamble and several articles of this document expressed recognition of the aspirations of indigenous peoples to gain control over their own institutions, ways of life, customs and beliefs, as well as economic development and their right to "maintain and strengthen their identities, languages and religions, within the framework of the states in which they live" (ILO Convention 169, Preamble, art. 4, 5). Official recognition of the rights to self-government and self-determination was probably the most important step towards rectifying historical injustices and transforming structural inequalities between the state and indigenous communities to the system of more equal and just co-existence. International norms related to principles of democratization and multiculturalism were an inspiration to change the official political doctrines during democratic transition in Latin America and initiated the process named "pluralist constitutionalism" based on particular amendments in constitutions. This process can be broken into three phases: a) The phase of multicultural constitutionalism (1982-1988); b) the phase of pluricultural constitutionalism (1988-2005), which developed the concepts of a "multiethnic nation" and "pluricultural state", and the most radical phase; c) of plurinational 
constitutionalism (2006-2009), which proposed the "re-founding of the State" (Lee Van Cott 2000; Baldi 2012).

The norms adapted by Convention 169 were also a prelude to a broader debate devoted to diversity and cultural plurality and to concerns about the negative consequences of the globalization process and the phenomenon of de-ethnization of contemporary indigenous communities. Many efforts have been made during the process of elaboration of the new conventions of the World Heritage Committee. The main goal was to fulfill the principles of participation and consultation rights, in line with the paradigm of the new model of multicultural policy and with the changes introduced as a result of the indigenous resistance movements. Through consultations with the un Permanent Forum on Indigenous Issues, international non-governmental organizations and representatives of the indigenous groups it was possible to gain a consensus and at the same time to develop documents of universal importance.

By adopting the UNESCO Universal Declaration on Cultural Diversity at its $31^{\text {st }}$ session in 2001, the UNESCO General Conference has illustrated the Organization's dedication to the preservation of cultural diversity with a specific reference to indigenous communities. Article 4 states, that: "The defense of cultural diversity is an ethical imperative, inseparable from respect for human dignity. It implies a commitment to human rights and fundamental freedoms, in particular, the rights of persons belonging to minorities and those of indigenous peoples. No one may invoke cultural diversity to infringe upon human rights guaranteed by international law, nor limit their scope" (UNESCO 2001).

Furthermore, the adoption of International Convention for the Safeguarding of Intangible Cultural Heritage during the $32^{\text {nd }}$ session of the General Conference in October 2003 reflected the efforts made by UNESCO not only for the preservation of all forms of cultural expression, but also for introduction of changes in the same process of nominations and any other project related to heritage management. Article 15 of the Convention stresses the need to involve local communities and groups, including indigenous peoples, in identifying intangible cultural heritage process and 
developing and implementing measures for its safeguarding. Thus, it is designed to be a bottom-up, participatory approach to heritage management and preservation: "Within the framework of its safeguarding activities of the intangible cultural heritage, each State Party shall endeavor to ensure the widest possible participation of communities, groups and, in some cases, individuals that create, maintain, and transmit such heritage, and involve them actively in its management" (unESCO 2003). The aforementioned World Heritage Convention of 1972 focuses on identifying and protecting tangible cultural heritage; thus, it concerns protecting the products of human creativity and ingenuity predominantly of the past and favors "classical" works produced by "great civilizations" of Western World. Whilst the Convention of 2003 shifts attention to safeguarding the knowledge, skills, and values behind material culture, concentrating more on the contemporary people and social processes.

The new Convention demonstrates therefore increased concern for protecting living cultures expressed in popular and "folkloric" traditions, recognizing their value to maintain the identity, self-esteem, and promoting the development of local communities (UNESCO 2003; Smith 2006: 106-113; Ruggles and Silverman 2009). A breakthrough regarding the commitment of the international community to promote cultural diversity, respect of culture rights and principles of participation and consultation was UnESCO Convention on the Protection and Promotion of the Diversity of Cultural Expressions, adopted during the General Conference meeting in Paris in October 2005 (in force since UN 2007).

The Convention makes explicit reference to the importance of the knowledge systems of indigenous peoples as a source of intangible and material wealth, and recognizes the importance of indigenous cultures and in particular the positive contribution of indigenous knowledge systems to sustainable development, as well as the need for its adequate protection and promotion (UNESCO 2005). The protection of indigenous peoples' cultural identity and cultural rights also represents a predominant theme throughout the whole text of the UNDRIP 2007. The UN Declaration includes a number of provisions affirming the right of indigenous peo- 
ples to practice, develop and revitalize their cultural and spiritual traditions and customs, as well as to maintain, control and protect elements of their tangible and intangible cultural heritage, traditional knowledge and traditional cultural expressions (articles 11, 12, 13, 25, 31 and 34, among others). Another important provision is the right to "not to be subjected to forced assimilation or destruction of culture" (article 8). Article 28 states, that "indigenous peoples have the right to redress, by means that can include restitution or, when this is not possible, just, fair and equitable compensation, for the lands, territories, and resources which they have traditionally owned or otherwise occupied or used, and which have been confiscated, taken, occupied, used or damaged without their free, prior and informed consent" Important in the context of the World Heritage Convention is article 32 (3), which requires States-parties to provide effective mechanisms for just and fair redress for any project or activities affecting the lands, territories or resources of indigenous peoples, and to take appropriate measures to mitigate adverse environmental, economic, social, cultural or spiritual impacts arising from such activities (UNDRIP 2007; Disko, Tugendhat, García-Alix 2014: 3-16; Gilbert 2014: 60-62).

On the occasion of the UNDRIP 2007 adoption, UNESCO's Director-General, Koïchiro Matsuura, stated: "UNESCO welcomes the General Assembly's approval of the United Nations Declaration on the Rights of Indigenous Peoples as a milestone for indigenous peoples and all those who are committed to the protection and promotion of cultural diversity and intercultural dialogue. The Declaration acknowledges the significant place that indigenous cultures occupy in the world's cultural landscape and their vital contribution to our rich cultural diversity, which constitutes, as the text's preamble reminds us, "the common heritage of humankind"' (Matsuura 2007). In a message on the International Day of the World's Indigenous People (2008) he also emphasized that the new un Declaration echoes the principles of the UNESCO Declaration on Cultural Diversity (2001) and related Conventions 2003 and 2005, which recognize the pivotal role of indigenous peoples as custodians of cultural diversity and biodiversity (Matsuura 2008). 
Those were indeed crucial years of legislative changes in social and cultural policies toward and with the participation of indigenous peoples. The process of management of the cultural heritage without the free, prior and informed consent of indigenous peoples has become a subject of hard criticism. In his 2012 report to the UN General Assembly, the former UN Special Rapporteur on the rights of indigenous peoples, James Anaya, remarked that: "Indigenous peoples have expressed concerns over their lack of participation in the nomination, declaration, and, management of World Heritage sites, as well as concerns about the negative impact these sites have had on their substantive rights, especially their rights to lands and resources" (Anaya 2012).

The new Declaration of UN (UNDRIP 2007), recognized as coherent with the principles of the UNESCO Universal Declaration on Cultural Diversity (2001) and related Conventions - the 2003 Convention for the Safeguarding of the Intangible Cultural Heritage, and the 2005 Convention on the Protection and Promotion of the Diversity of Cultural Expressions, identifies the pivotal role of indigenous peoples as custodians of cultural diversity and biodiversity. Many critics point out, however, that despite having opted for a participative turn and a closer link with indigenous peoples' rights, the 2003 and 2005 Conventions, as well as the un Declaration 2007 do not seem to have resolved the problems caused by the excessive interference of "heritage agents" or national interests. As a result of forced displacement, deprivation of access to the natural resources of their territory, problems with access to education and limited access to the benefits of economic development, indigenous peoples are not able to protect their cultural heritage and transmit its elements (values, traditions) from generation to generation. The elements of local patrimony are inserted in a global market that converts them into merchandise, and the excessive search for something "authentic", "traditional", and good for tourist consumption causes a static and artificial representation of their "re-invented" (or sometimes invented) and "sterile" heritage, with more folklore and performance than tradition and authenticity. The problem is also the lack of consistency and coherence between indigenous' legislation and various 
specific national laws (such as those on mining, agricultural promotion, water management or exploitation of forests), whose application may affect the rights of indigenous communities (Endere 2014).

As has been mentioned, violation of indigenous rights to participate and to be adequately consulted and involved in the management and protection of heritage can be explained by the fact that the World Heritage Convention does not give any particular recognition of the rights of indigenous peoples over cultural and natural heritage, which in turn could be explained by adoption of this document at the time, when international law in this area was little developed and more paternalistic (vide ILO Convention 107). Subsequently devised and frequently updated Operational Guidelines, also, did not contain any provisions directly related to guarantee of the rights of indigenous peoples, but only general recommendations for states-parties to ensure the participation of a wide variety of stakeholders (including site managers, local and regional governments, local communities, non-governmental organizations (NGOS) and other interested partners) in the identification, nomination, and protection of World Heritage properties. However, Disko, Tugendhat, and García-Alix noted:

This approach, which subsumes indigenous peoples into a wider category of stakeholders such as local communities, NGOs, and other interested parties, negates indigenous peoples' status and rights under international law, including their right to self-determination and their collective rights to their lands, territories, and resources. Following the principles of the UNDRIP, indigenous peoples must be treated as rights-holders and key decision-makers whose consent has to be sought in the case of activities affecting their rights, and not merely lumped together with a wide variety of 'stakeholders', who may or may not be included in decision-making processes (2014: 23).

Due to many concerns raised by indigenous peoples in relation to World Heritage, all three of the un mechanisms specific to indigenous peoples (un Permanent Forum on Indigenous Issues, un Expert Mechanism on the Rights of Indigenous Peoples and un Special Rapporteur on the Rights of Indigenous Peoples) have called on the World Heritage 
Committee, UNESCO and the advisory bodies to revise the Convention's procedures and establish an appropriate mechanism of corrective action aligned with the World Heritage Convention is applied. The urgent need to reform the Operational Guidelines through which the World Heritage Convention is implemented was particularly emphasized so that they meet the standards set out by the UNDRIP 2007. To facilitate such efforts, the United Nations Development Group (UNDG) has elaborated Guidelines on Indigenous Peoples' Issues on the basis of the UNDRIP 2007, which provide "lines of action for planning, implementation, and evaluation of programs involving indigenous peoples". They are meant to "assist the un system to mainstream and integrate indigenous peoples' issues in processes for operational activities and programs at the country level", and set out "the broad normative, policy and operational framework for implementing a human rights-based and culturally sensitive approach to development for and with indigenous peoples" (UNDG 2008: 3; Disko 2010: 171). The UN Human Rights Council's Expert Mechanism on the Rights of Indigenous Peoples (EMRIP), by drawing attention to Articles 41 and 42 of the UNDRIP 2007 has encouraged the World Heritage Committee "to elaborate, with the full and effective participation of indigenous peoples, changes to the current procedures and operational guidelines and other appropriate measures to ensure that the implementation of the World Heritage Convention is consistent with the United Nations Declaration on the Rights of Indigenous Peoples and that indigenous peoples can effectively participate in the World Heritage Convention's decision-making processes" (EMRIP 2012: 7; Disko, Tugendhat, Garcia-Alix 2014; Gilbert 2014). The Committee should ensure that indigenous peoples are treated as rights-holders and key decision-makers, whose consent must be obtained, and not as a wide group of a variety of "stakeholders" to be "consulted" in decision-making. The full and effective participation of indigenous peoples in the identification, nomination, management and protection of World Heritage sites has to be a standard, and not an exception. ${ }^{11}$ As a result, in July 2015

${ }^{11}$ It is worth to mention, that the celebrations of the World Heritage Convention's 40th anniversary, held by UNESCO in 2012 under the theme of "World Heritage and Sus- 
the members of the World Heritage Committee reached an agreement to update the Operational Guidelines for the Implementation of the World Heritage Convention, adopted in October 2016. This document states that indigenous peoples should be partners of governments in the whole process of protection and conservation of World Heritage sites located in their territories, therefore it is recommended that any process of registration, declaration, and management of heritage that affects the interests of local communities will be executed according to indigenous rights at a national and international level (Operational Guidelines for the Implementation...).

The particular role of UNESCO in the above described processes of recognition of the rights and re-appropriation of the indigenous peoples' heritage was significant and well defined. At the beginning of the First International Decade of the World's Indigenous Peoples (1995-2004), UNESCO set out to promote the full participation of indigenous peoples in devising, implementing and monitoring policies and actions affecting them. The main goal of the Programme of Action elaborated and adopted by un General Assembly was: "Promoting full and effective participation of indigenous peoples in decisions which directly or indirectly affect their lifestyles, traditional lands and territories, their cultural integrity as indigenous peoples with collective rights or any other aspect of their lives, considering the principle of free, prior and informed consent" and "Redefining development policies that depart from a vision of equity and that are culturally appropriate, including respect for the cultural and linguistic diversity of indigenous peoples" (International Decade of the World's Indigenous Peoples). In December 2004, the un General Assembly proclaimed the Second International Decade of the World's Indigenous Peoples

tainable Development: the Role of Local Communities" was focusing not only on the "issues pertaining to the well-being and responsibilities of local communities", but also intended to provoke a critical and constructive debate aimed at increasing attention on the experiences of indigenous peoples with the Convention. The celebration was seen as "an opportunity for the international community involved in cultural and natural heritage conservation to reflect on the achievements of the Convention to date as well as to take stock of the challenges with which it is confronted". 
(2005-2014) with the principal objective of "further strengthening international cooperation for the solution of problems faced by indigenous people in such areas as human rights, the environment, development, education, and health". In the Programme of Action for the Second International Decade... the role of UNESCO agendas in the recognition and implementation of a new direction in heritage policy and a new paradigm of the relations with indigenous peoples were indicated in paragraphs 15 and 16: "It is recommended that UNESCO should intensify efforts to promote and support the recovery of indigenous heritage and the oral tradition and ancient writings of indigenous peoples with a view to recognizing them as heritage of humanity under the framework of the Convention Concerning the Protection of the World Cultural and Natural Heritage and the Convention for the Safeguarding of the Intangible Cultural Heritage", and "UNESCO is urged to establish mechanisms to enable indigenous peoples to participate effectively in its work relating to them, such as the programmes on endangered languages, education, literacy, nomination of indigenous sites in the World Heritage List and other programmes relevant to indigenous peoples" (Programme of Action 2005).

Lastly, it is worth to mention that similar guidelines adopted at international level refer to proper protection, safeguarding, and promotion of these elements of the cultural heritage that are recognized globally and inscribed on the Representative List of the Intangible Cultural Heritage of Humanity. The Ethical Principles for Safeguarding Intangible Cultural Heritage published by UNESCO in reference to the Convention of 2003 represent a set of principles that are widely accepted as constituting good practices for governments, organizations and individuals directly or indirectly affecting intangible cultural heritage, in order to ensure its viability, thereby "recognizing its contribution to peace and sustainable development". The Ethical Principles are complementary to the Convention, the Operational Directives for the Implementation of the Convention and national legislative frameworks. They are intended to serve as basis for the development of specific codes of ethics and tools adapted to local and international heritage agendas in order to respect and fulfill the principles 
of collaboration, negotiation and participation of communities, upon their free, prior, sustained and informed consent, as recommended in modern heritage policy adopted by in UN-system (Ethical principles for Safeguarding ...).

The most significant changes in all the documents are therefore connected with the relations between the states, international agendas and indigenous peoples regarding cultural issues: the recognition of the principles of cultural pluralism and the right of indigenous people to autonomy in maintaining, developing and transmitting to the next generations the elements of their material and immaterial heritage. It could be an answer to the demands for much broader participation in the patrimonial issues brought to the competent forums of the United Nations by various indigenous movements and organizations. The re-appropriation and resignification of the indigenous peoples' cultural heritage are recognized by many as an essential and crucial part in the indigenous struggles for the decolonization of inter-ethnic relations, political discourse and legislative system on both national and international level.

Good Practices in the PRESENT AND CHALLENGES FOR THE FUTURE

The global processes of socio-political changes, in particular, those related to the concept of decolonization, cultural plurality, and respect for cultural rights introduce both positive phenomena with regards to the use and protection of cultural heritage, as well as negative aspects that lead to political and economic appropriation or destruction of its elements. Principles of pluricultural policy and the process of institutionalization of attitudes related to this sector of public policy established the obligations of the states, as well as the rights of indigenous peoples, to forced mutual respect for the available registration, preservation, management, and safeguarding of heritage elements, both tangible and intangible. 
In the case of Latin America, the formal incorporation of cultural rights in the legislative and constitutional framework has been one of the significant advances in the protection and safeguarding of cultural heritage in reference to the recognition of the rights of indigenous peoples. It is not an easy process and we are aware that in many countries where the cultural heritage of indigenous peoples is perceived as a particularly attractive product for the development of mass tourism (and is therefore evaluated primarily through the prism of economic benefits that can contribute to regional development) the principles of participation, consultation and free consent in the whole process of heritage management or during the process of designation of the World Heritage sites still remains under the total control of the state, and mostly at the level of the letter of law, but not of the full implementation. Nonetheless, both the struggle of the indigenous peoples themselves, who decide to take advantage of existing legal mechanisms and the growing awareness of socio-political changes on the local and national scale have brought some progress in the matter. The critiques of the work of the World Heritage Committee and subsequent decisions made both at international level and at the level of national legislative structures have contributed to the revision of current practices and procedures used in identification, inventories and research projects. Changes in the promotion and management of cultural heritage in which indigenous peoples become not only stakeholders but also active actors render gradually visible. The crucial issues are the processes of participation and consultation, as they can generate benefits focused on education, the increase of self-esteem and the sense of belonging among indigenous communities' members. They can also contribute to archaeological research helping to locate new remains advancing alternative ways of interpretation (Kellet 2006; Herrera 2010; Burón Díaz 2012; Asensio 2013).

Some groups of indigenous peoples discovered the benefits and welcomed the inscription on the World Heritage List of sites that are within their territories. They understand that the World Heritage List can play a decisive role in their life, by helping them protect their lands. The World 
Heritage rank grants international conservation status to protected areas and thereby reinforces the prohibitions against any action that may be contrary to their management (i.e. urban encroachment development pressures, extractive industry activities). In monitoring the state of conservation of World Heritage sites, the World Heritage Committee and/or its advisory bodies may call on states-parties to improve indigenous peoples' participation in the management and decision-making processes or to enhance benefit-sharing mechanisms of safeguarding and protection of their heritage elements - thus there is some international control in favor of indigenous peoples rights and status. The "community participation" seems to be also the most important and demanded type of involvement of the population in the entire process of nomination, documentation, limitation and management of heritage elements proposed and developed by the "heritage agents", because is stimulating conservation of the monuments and can serve as an early warning against destruction and looting of heritage sites.

The Qhapaq Ñan Project from Peru can be an example of implementation of the good practices in public policy dedicated to the protection and proper management of cultural heritage of indigenous peoples, as well as introduction of the concept of the heritage understood as the social and political process and space of contact and negotiations between various interest groups. The Qhapaq Nan, also known as The Andean Main Road, is a road system formed by a network of more than $70,000 \mathrm{~km}$ of pre-Hispanic roads located throughout the Andean region, in the territory of the former Inca State Tahuantinsuyu. In March 2002, during the World Heritage Meeting in Montevideo, on the initiative of the Peruvian representation, the countries Colombia, Ecuador, Bolivia, Chile, Argentina, and Peru signed a commitment to promote joint actions in favor of the Qhapaq Nan system and its inscription on the unESCO World Heritage List. $1^{\text {st }}$ of February of 2013 the representatives of the six countries presented the nomination file of the Qhapaq Nan to the Unesco World Heritage List. In June 2014 the final decision of inscription was made during the $38^{\text {th }}$ session of the World Heritage Committee in Doha, Qatar. Since 
2003, the National Institute of Culture of Peru (since 2011, the Ministry of Culture of Peru), through the Qhapaq Ñan Project, is developing a field research work in order to identify, register and evaluate the social and cultural value of the network of roads and archaeological sites related to Qhapaq Nan located in the Peruvian territory. Initially the entire nomination process was criticized (mainly by the academic community), as an example of vertical politics up-down (hegemonic discourse of patrimonialization process control by the State), commercialization and neocolonial relations between the State and indigenous peoples (Korstanje, García 2007; Jallade 2011; Losson 2017). However, the method of work introduced and carried out for several years by Project members became the policy of dialogue, participation, consultation and joint management of elements of the Qhapaq Ñan, consistent with the guidelines included in UN-system documents ratified by Peru. As the Andean inhabitants continue to use the pre-Hispanic roads, the Qhapaq Nan is recognized as a means for social, environmental, educational and economic development of local populations, and the means of the promotion of the social use of cultural and natural heritage in the process of strengthening their identity and self-esteem (Ruiz Rubio 2014, Proyecto Qhapaq Ñan). Within the framework of the communitiees participation principles, the Project's technical team meets with the authorities and residents in various regions of the country to validate the protected areas of the Inca Trail. At the same time, the idea of informative meetings about the registration process and documentation of the Qhapaq Nan, as well as the educational initiatives, workshops and special walks "Traversing roads with history and tradition" are carried out jointly by the representatives of Qhapaq Ñan Project, Ministry of Culture of Peru and members of indigenous communities.

The dynamically developing issue of mass-tourism, and particularly the phenomena of cultural tourism, with the central point of cultural heritage (both past and present) is of crucial importance during last decades, provoking a debate about the principles of management and protection of culture heritage as well as respect for indigenous culture rights as promoted by UNESCO, UNDPIR 2007 and other heritage agendas. This vast and 
multidisciplinary subject is connected with phenomena of "Effect of the List", which in many cases has led to the banalization, commercialization, as well as political and economic appropriation of indigenous peoples' territories or heritage elements. However, we have to consider the impact of cultural tourism as a very ambivalent phenomenon. While during $20^{\text {th }}$ century members of indigenous populations were not allowed to make any decisions regarding the development of the tourist movement, being at most an attractive addition to the picturesque ancient ruins described in the guidebooks, the turn of the century brought gradual changes. The renaissance of indigenous values plays an especially important role in the cultural tourism industry, and indigenous peoples, making use of global notions of identity and universal rights to self-determination, become more and more aware of their role as stakeholders of cultural heritage and more successful in defending their rights to the participation in the management of their knowledge and patrimony. There are projects and special campaigns organized by indigenous groups aiming to control the use of heritage places, as well as the elements of intangible heritage. Their involvement in the process of enhancing the cultural value and development of cultural tourism generates economic and social benefits: it gives them the opportunity to show the non-indigenous groups that their culture is not only "some artefacts" in museums, but it is a vital and real source of their identity. An important part of the process of growing participation of indigenous peoples in the development of cultural tourism is also the emergence of a new model of museums and a new paradigm of essential museum functions.

At the turn of $20^{\text {th }}$-century various institutions in Latin America countries had responded to indigenous concerns connected with proper presentation, explanation, and guardianship of the elements of their patrimony by considering and integrating alternative curatorship and management practices. Indigenous curatorial methods introduced during last few decades intend to protect both the material and spiritual integrity of exhibited objects, reflecting a particular community's religious practices and regarding the use and treatment of certain kinds of artefacts. These meth- 
ods might include the separation of culturally sensitive or sacred objects from general collections or the segregation of objects defined by gender, age or religious status. In parallel, the rise of community-based museums (sometimes called "living museums") has provided new opportunities to explore and articulate local values in cultural heritage. One of the first initiatives in Latin America was the National Program of Community Museums (Programa Nacional de Museos Comunitarios), established in 1980 by National Coordination of Museums and Exhibitions of the National Institute of Anthropology and History in México. Up to date, more than one hundred community-based museums were founded in 17 states of México (Burón Díaz 2012; González Meza 2016). A significant number of community-based museums were also founded by indigenous peoples in Chile, Bolivia, and Colombia. Community-based museums do not only serve as an exhibition site, but they are a space where indigenous communities carry out actions of acquisition, protection, research, conservation, exhibition and dissemination of their heritage. They exemplify holistic approaches to heritage preservation that are integrated into broader social structures and ongoing social practices. In that sense, community-based museums also serve as instruments of control and negotiation in the process of decolonization (Walker and Ostrove 1995; Van Geert 2016).

In many Latin American countries, indigenous peoples' postulates of respect of the principles of consultation and participation, recognition of the principles of sustainable development and holistic perception of cultural heritage can be assumed as a response to the search for best practices and standards in cultural policies that alike protect the heritage, and maintain the integrity and identity of the indigenous communities. The aim is that these policies depart from the discriminatory and paternalistic practices of state (and international) agendas and the false perception of indigenous communities only through the prism of an attractive, additional element to the whole "tourist package". 
REFERENCES

ASENSIO, RAúl H. "¿De qué hablamos cuando hablamos de participación comunitaria en la gestión del patrimonio cultural?". Revista Argumentos. 7.3 (2013). Online http://revistargumentos.org.pe/participacion_patrimonio.html [access online: 09.09.2017].

ASHWORTH, GREGORY. "Sfragmentaryzowane dziedzictwo: sfragmentaryzowany instrument sfragmentaryzowanej polityki". Monika Murzyn, Jacek Purchla (eds.). Dziedzictwo kulturowe w XXI wieku. Szanse $i$ wyzwania. Krakow: Mi dzynarodowe Centrum Kultury, 2015. 29-42. ASKEW, MARC. "The Magic List of Global Status. unESCO, World Heritage and the Agendas of States". Sophia Labadi, Colin Long (eds.). Heritage and Globalisation. London \& New York: Routledge Taylor \& Francis Group, 2010. 19-44.

BALDI, CÉSAR Augusto. "New Latin American Constitutionalism: Challenging Eurocentrism \& Decolonizing History". Critical Legal Thinking. Law and the Political (2012). Online www.criticallegalthinking. com./2012/02/ [access on line 23.01.2019].

GeORGETOWn UnIVERSITY. Base de datos politicos de las Américas. Conservación del patrimonio cultural de la nación. Online: http://pdba. georgetown.edu/Comp/Cultura/conservacion.html [access on line 09.09.2017].

Baud, Michiel and AnNelou YPeiJ. "Cultural Tourism in Latin America. An Introduction". Michiel Baud y Annelou Ypeij (eds.). Cultural Tourism in Latin America. The Politics of Space and Imagery. Leiden-Boston: CEDLA Latin American Studies. 96, 2009: 1-16.

BERTACCHINI, ENRICO et al. "The politicization of unEsCo World Heritage decision making". Public Choice 167. 2. 2016. Online: DOI 10.1007/ s11127-016-0332-9.

Burón DíAZ, MANuEL. "Los museos comunitarios mexicanos en el proceso de renovación museológica”. Revista de Indias. LXXII. 254 (2012): 177-212. CleERe, Henry. The Impact of World Heritage Listing. Paris: ICOMOS, 2011. 
Daes, ERICA-IRENe. Principles and Guidelines for the Protection of the Heritage of Indigenous People. New York: un Commission on Human Rights, 1997.

Disko, Stefan. "World Heritage Sites in Indigenous Peoples' Territories: Ways of Ensuring Respect for Indigenous Cultures, Values, and Human Rights". Dieter Offenhäußer, Walther Ch. Zimmerli and Marie-Theres Albert (eds.). World Heritage and Cultural Diversity. Cottbus: German Commission for UNESCO / Heritage Studies / Brandenburg University of Technology, 2010: 167-177.

\& Helen Tugendhat (eds.). World Heritage Sites and Indigenous Peoples' Rights. Copenhagen: IWGIA, 2014.

Disko, Stefan, Helen Tugendhat \& Lola Garcia-Alix. "World Heritage Sites and Indigenous Peoples' Rights: An Introduction". Stefan Disko $\&$ Helen Tugendhat (eds.). World Heritage Sites and Indigenous Peoples' Rights. Copenhagen: IWGIA. 2014. 3-37.

ENDERE, María L. "Archaeological Heritage Legislation and Indigenous Rights in Latin America: Trends and Challenges". International Journal of Cultural Property 21 (2014): 319-330.

Ethical Principles for Safeguarding Intangible Cultural Heritage. Paris: UNESCO 2003. Online: https://ich.unesco.org/en/ethics-and-ich-00866 [access online: 09.09.2017].

GARCIA, PABLO. "From Folk History to Empathy: Contesting Heritage Values in Chinchero, Peru". Journal of Heritage Studies 23 (2017): 335-346. GILBERT, JÉRÉMIE. "Indigenous Peoples' Heritage and Human Rights". Stefan Disko \& Helen Tugendhat (eds.). World Heritage Sites and Indigenous Peoples' Rights. Copenhagen: IWGIA, 2014. 55-63.

Gnecco, Cristóbal \& Patricia Ayala Rocabado (eds.). Pueblos indígenas y arqueología en América Latina. Bogotá: Fundación de Investigaciones Arqueológicas Nacionales / Banco de la República / Universidad de los Andes, 2010.

GonzÁlez Meza, Yadur Nahel. "Museos comunitarios de México. Ecos de la diversidad cultural a través del patrimonio". Fabien Van Geert, Xa- 
vier Roigé \& Lucrecia Conget (eds.). Usos políticos del patrimonio cultural. Barcelona: Universitat de Barcelona, 2016. 79-100.

Herrera, AlEXANDER. "iArqueología indígena en el Perú?". Cristóbal Gnecco \& Patricia Ayala Rocabado (eds.). Pueblos indígenas y arqueología en América Latina. Bogotá: Fundación de Investigaciones Arqueológicas Nacionales / Banco de la República / Universidad de los Andes, 2010. 137-159.

JALLADE, SÉBASTIEN. "La reinvención de las rutas incas: representaciones y construcción de la memoria en el Perú (2001-2011)". Droit et Cultures 62 (2011: 119-137).

KANIA, MARTA. Machupicchu. Mi dzy archeologi i polityk. Kraków: Wydawnictwo Universitas, 2013.

. "Protección y salvaguarda del patrimonio cultural de los pueblos indígenas en Perú". Gaya Makaran (ed.). ¿Estado nación o Estado plural? Pueblos indígenas y el Estado en América Latina (siglo XXI). México: Cialc-unam, 2017. 121-146 (Colección Política, Economía y Sociedad en América Latina y el Caribe).

Kirshenblatt-Gimblett B., Destination Culture. Tourism, Museums and Heritage, Berkeley: University of California Press, 1998.

Korstanje, M. Alejandra, Jorgelina GarCía AzCÁRATE. "The Qhapaq Ñan Project: A Critical View”. Archaeologie 3.2 (2007): 116-131.

LABADI, SOPHIA, COLIN Long (eds.). Heritage and Globalisation. London \& New York: Routledge Taylor \& Francis Group, 2010.

LeE Van CotT, Donna. The Friendly Liquidation of the Past: The Politics of Diversity in Latin America. Pittsburgh: University of Pittsburgh Press, 2000.

LOSSON, PIERRE. “The Inscription of Qhapaq Nan on UnESCO's World Heritage List: A Comparative Perspective from the Daily Press in Six Latin American Countries". International Journal of Heritage Studies. DOI 10.1080/13527258.2017.1287117.

Martorell, AlBerto. Machu Picchu: patrimonio cultural en peligro. Lima: Malze, 2000. 
MaTSUURA, Kö̈CHIRO. "Message from the Director-General of unESCO on the Occasion of the Approval of the United Nations Declaration on the Rights of Indigenous Peoples". Paris: UnEsCo, 2007. Online: http://portal.unesco.org/en [access online: 30.08.2017].

Unesco. "International Decade of the World's Indigenous Peoples: the Commission on Human Rights". Cultural Survival Quarterly Magazine (1994). Online: https://www.culturalsurvival.org/publications/cultural-survival-quarterly/international-decade-worlds-indigenous-peoples-commission [access online: 20.07.2017].

. Message from Mr. Koïchiro Matsuura, Director-General of UNESCO, on the occasion of the International Day of the World's Indigenous People, 9 August 2008. Paris: unESCO, 2008. Online: http:// portal.unesco.org/en [access online: 09.09.2017].

Posern-Zieliński, AleKSANDER. "The State and the Indigenous Peoples in Latin America". Ryszard Stemplowski (ed.). On the State of the Latin American States. Kraków: Akademia Frycza Modrzewskiego, 2009. 301-384.

Ruggles, D. Fairchild, Helaine Silverman. "From Tangible to Intangible Heritage". D. Fairchild Ruggles \& Helaine Silverman (eds.). Intangible Heritage Embodied. London: Springer Science Business Media, 2009. 1-14.

RUIZ RuBIO, RODRIGO. El rol de la participación comunitaria en el Proyecto Qhapaq Ñan. Lima: Proyecto Qhapaq Nan. Sede Nacional, 2014.

SIEDER, RACHEL (ed.) Multiculturalism in Latin America. Indigenous

Rights, Diversity and Democracy. London: Palgrave Macmillan, 2002 (Institute of Latin American Studies Series).

SMith, LauRAJANE. Uses of Heritage. London/New York: Routledge, 2006.

Stavenhagen, Rodolfo. "Indigenous Peoples and the State in Latin America: An Ongoing Debate". Rachel Sieder (ed.). Multiculturalism in Latin America: Indigenous Rights, Diversity, and Democracy. London: Palgrave Macmillan, 2002. 24-44.

. "Indigenous Peoples as New Citizens of the World". Latin American and Caribbean Ethnic Studies 4.1 (2009): 1-15. 
Stavenhagen, Rodolfo. Derechos indigenas y derechos bumanos en América Latina. México: El Colegio de México / Instituto Interamericano de Derechos Humanos, 2012.

unDG. Guidelines on Indigenous Peoples Issues. New York: United Nations Development Group, 2008.

Walker, Patrick \& Clarine Ostrove. "The Aboriginal Right to Cultural Property". UBC Law Review. 13 (1995): 13-28.

VAn GeERT, Fabien, Havier Roigé \& LuCReCia CONGeT (eds.). Usos políticos del patrimonio cultural. Barcelona: Universitat de Barcelona, 2016.

\section{DOCUMENTS}

ANAYA, James (2012). "Report of the Special Rapporteur on the rights of indigenous peoples", New York: UN Documents A/HRC/21/47. Online: http://unsr.jamesanaya.org/study/report-a-hrc-21-47-2012 [access online: 09.09.2017].

Cobo Martínez, José. "Study of the Problem of Discrimination Against Indigenous Populations". New York: un Document E/CN.4/Sub.2/1986/7 and Add. 1-4.

United Nations Human Rights Council. EMRIP. "Report of the Expert Mechanism on the Rights of Indigenous Peoples on its $5^{\text {th }}$ session, Geneva, 9-13 July 2012. A/HRC/21/52". Online www. Refworld.org/docid/5051b60f2.html [access online: 20.07.2017].

ILO Convention 169 "International Labour Organization Convention concerning Indigenous and Tribal Peoples in Independent Countries", 1989. Online: www.ilo.org/indigenous/Conventions/no169/en/index. html [access online: 01.02.2018].

unESCO. "Operational Guidelines for the Implementation of the World Heritage Convention”, 2016. Online: http://whc.unesco.org/en/guidelines [access online: 01.02.2018]. 
un Organization of International Tourism. "Panorama OMT del Turismo Internacional", 2016. Online: http://www.e-unwto.org/doi/pdf/10. 18111/9789284418152 [access: 09.09.2017].

un General Assembly. "Programme of Action" 2005. a/60/270/Add.1, 2005. Online: https://documents.un.org/doc/UnDOC/GEN/N05/473/33/PDF/ N0547333.pdf?OpenElement [access online: 09.09.2017].

unESCO Convention. "Convention Concerning the Protection of the World Cultural and Natural Heritage", 1972. Online: http://whc.unesco.org/ archive/convention-en.pdf [access online: 01.02.2018].

UNESCO Declaration. "Universal Declaration on Cultural Diversity", 2001. Online: http://unesdoc.unesco.org/images/0012/001271/127162e.pdf [access online: 01.02.2018].

unESCO Convention. "Convention for the Safeguarding of the Intangible Heritage", 2003. Online: http://unescodoc.unesco.org/images/0013/ 001325/132540e.pdf [access online: 01.02.2018].

unESCO Convention. "Convention on the Protection and Promotion of the Diversity of Cultural Expressions", 2005. Online: http://unescodoc.unesco.org/images/0014/001429/142919e.pdf [access online: 01.02.2018].

UNDRIP. "United Nations Declaration on the Rights of Indigenous Peoples", 2007. Online: http://www.ohchr.org/EN/Issues/PPeoples/Pages/Declaration.aspx [access online: 01.02.2018]. 